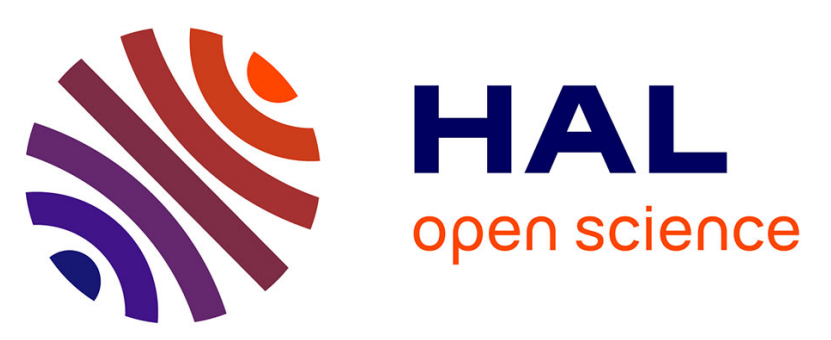

\title{
FORMATION OF HIGH-CURRENT AND DENSITY ELECTRON BEAM ON GALLIUM CATHODE WITH THE LIMITED EMISSION SURFACE
}

\author{
G. Fursey, V. Zhukov, L. Shirochin, Alexander Aleksandrov, S. Galuso
}

\section{- To cite this version:}

G. Fursey, V. Zhukov, L. Shirochin, Alexander Aleksandrov, S. Galuso. FORMATION OF HIGHCURRENT AND DENSITY ELECTRON BEAM ON GALLIUM CATHODE WITH THE LIMITED EMISSION SURFACE. Journal de Physique Colloques, 1979, 40 (C7), pp.C7-415-C7-416. 10.1051/jphyscol:19797203 . jpa-00219183

\section{HAL Id: jpa-00219183 https://hal.science/jpa-00219183}

Submitted on 1 Jan 1979

HAL is a multi-disciplinary open access archive for the deposit and dissemination of scientific research documents, whether they are published or not. The documents may come from teaching and research institutions in France or abroad, or from public or private research centers.
L'archive ouverte pluridisciplinaire HAL, est destinée au dépôt et à la diffusion de documents scientifiques de niveau recherche, publiés ou non, émanant des établissements d'enseignement et de recherche français ou étrangers, des laboratoires publics ou privés. 


\title{
FORMATION OF HIGH-CURRENT AND DENSITY ELECTRON BEAM
} ON GALLIUM CATHODE WITH THE LIMITED EMISSION SURFACE

\author{
G.N. Fursey, V.M. Zhukov, L.A. Shirochin, A.F. Aleksandrov and S.Y. Galuso.
}

The Leningrad Electrotechnical Commination Institute.

As was shown in papers $11,2 \%$, the explosive emission ( $\mathrm{E}$ ) of solid and liquid gallium cathodes is characterised by high stability of current. The authours of paper / $/ 3 /$ had shown that the use of the point gallium cathodes with the limited emission surface permits to decrease the space charge in a diode and to reveal the emission properties of $\mathrm{EE}$. Use of such cathodes in diodes of microsecond duration with magnetic insulation makes it possible to obtain sharply focused electron beans with a total current about $300 \mathrm{~A}$, energy of $150 \mathrm{Kev}$ and the current density measured on the target of about $105 \mathrm{~A} / \mathrm{cm}^{2} / 4 /$.

It is known $15,6,7 /$, that in magnetically insulated diodes the potencial drop and the influence of the magnetic field of electron beam on the transporting field decrease when the ratio $\mu=z_{i} / z_{e}$ tends to unity, where $z_{i}$ and $z_{e}-i n-$ ternal and external radii of the beam. These are the beams with a weak diamagnetism, $i . e$. with a small ratio of transversal and the total energies of electrons. In the conventional constructions of diodes the emitting cathode surface is unlimited and the majority of electrons is emitted in the direction which is normal to magnetic force lines. It leads to greater diamagnetism in the beam.

We made the butt-ended cathode of special form (the emitting surface facing the guidance channel). In this case the transversal motion of electrons is possible because of nonuniformity of electric field near the cathode edge

$\left[z_{c}=(1+4) \cdot 10-2 \mathrm{~cm}\right]$ and the influence of high space charge of the beam electrons. The first factor may be diminished by deeping the cathode edge. For the width " $a$ " of cathode ring about $10^{-2} \mathrm{~mm}$. the edge sinking is of the same order of value. The second factor is decreased by limiting the emitting surface of cathode $13 /$.

As was noticed in $/ 5 /$, processes in diode influence greatly formation and current transporting of the beam. Nevertheless versatility of processes on the cathodes with unlimited and continuously changing emitting surface makes it difficult to completely solve the problem of beam formation in a whole beam - target gap.
We supposed that in case when the butt-ended cathode with limited emitting surface is used the exact theory developed in $16,7 /$. may be used to describe the diode part of beam formation too. Estimates made in $16,7 /$ show that it is sufficient to create the magnetic field $B_{e}=8 \mathrm{KH}$ is to provide the guidance of beam with the external radius $z_{e}=0.5 \mathrm{~cm}$, energy $/=2$ beam current Is $=10 \mathrm{kA}$. It is also show in $/ 7 \%$, that increase of magnetic field upto $B>$ Be produce compressing of annular beam which results in reduction of external radius. It may be supposed that the beam which is formed in such a manner has the ratio $\mu \approx 1$ and its diameter is determined by the cathode emitting surface Dc. It makes possible to accord the diode impedance with the drift space of accelerator by varing the cathode geometry. Analysis of experimental data may be carried out basing on the results $/ 8 /$, which lead to the following formula, supposing the small diamagnetism of the beam:

$$
I=\frac{m c^{3}}{e}\left(y^{2 / 3}-1\right)^{3 / 2} /\left(\frac{q}{z_{e}}+2 \ln \frac{z_{0}}{z_{c}}\right)(1)
$$

where $Z_{o}$ - radius of drift tube; $\gamma$ - total electron energy; $a+$ ring beam width.

The experimental test of validity of supposition concerning small diamagnetism of beams formed on cathodes with limited emitting surface is the subject of present paper. Fig.1 demonstrates the scheme of high voltage diode, measuring devices and gallium cathode. Total diode current Io, drift tube and anode electrodes current $I_{A}$, evacuated beam current $I_{b}$ and accelerating voltage were fixed in experiment. The vacuum was of 10-5 Torr. Teflon was used as a cathode insulation. We used the cathode with $\mathrm{Dc}=10 ; 15 ; 22 \mathrm{~mm}$ in diameter with the ring cathode thickness $a=0.2 \mathrm{~mm}$. The cathode was immersed in homogeneous magnetic field $B=10 \mathrm{kHs}$. Distance between the emitting edge of cathode and the wall of drift tube was $d_{\alpha-c}=2 \mathrm{~cm}$. The drift space was equal to $100 \mathrm{~mm}$ and its diameter was $26 \mathrm{~mm}$.

Fig.2,3 give the oscillograms of current and voltage and current to voltage characteristics of the evacuated beam for different cathodes. Fig. 3 gives the values of current calculated (dashed lines) by formula (I) neglecting the po- 


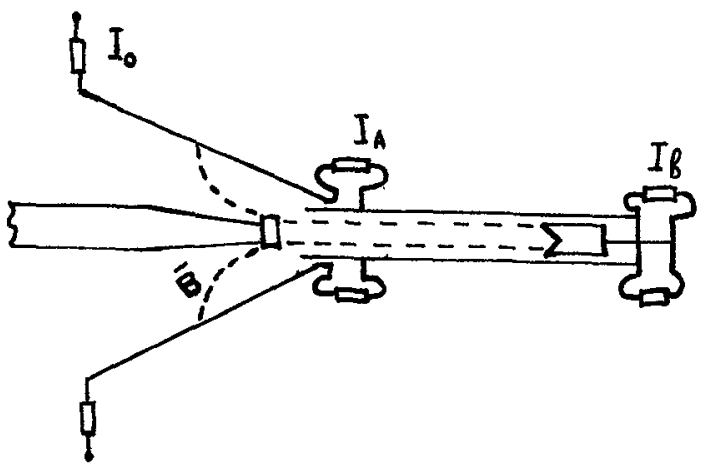

Fig. 1 The scheme of bigh voltage diode and gallium cathode.

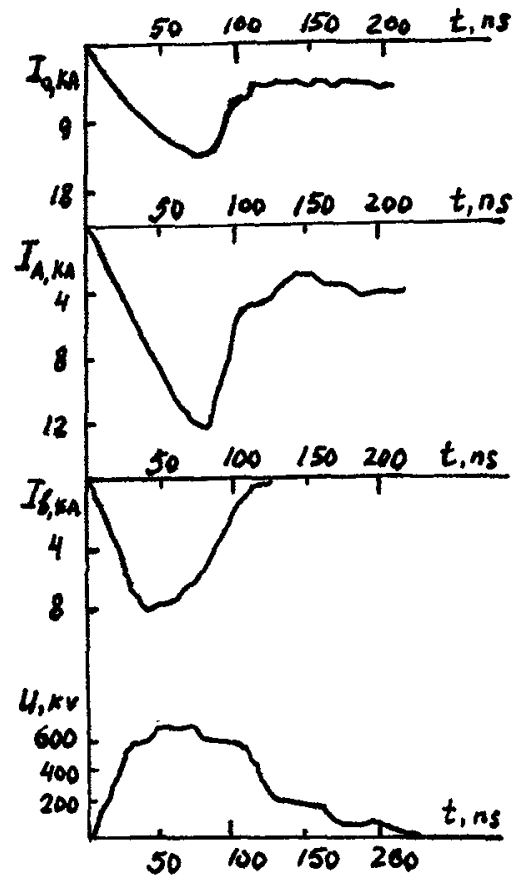

Fis.2. The oscillograms of currents and voltage.

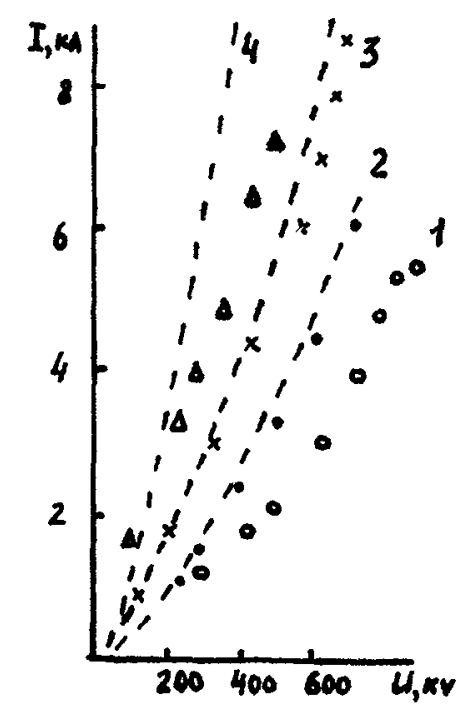

Fig.3 current to voltage characteris tics. 1 - steel cathode.2-gallium cathod $\div D c=10 \mathrm{~mm} 3-D c=15 \mathrm{~mm}, 4-D c=22 \mathrm{~mm}$

tencial drop in the beam. It corresponds to the model of "Thin" annular beam, $a=0$. For comparison, on the same pigure we give the data for the steel cylindrical cathode with unlimited emitting surface. The significant difference between the evacuated beam and the ealculated beam current for the cathode with $\mathrm{Dc}=22 \mathrm{~mm}$ may be explained by the fact that electron Iarmour radius in the transporting field is of the same order of value as the distance between emitting edge of cathode and drift channel wall. This results in the loss of beam in a drift space.

Thus, the use of butt-ended cathodes with iimited emitting surface permits produce thin annuler beams and to calculate current in diode with magnetic insulation over the whole space of formation and beam transporting by approximate formulae (I).

\section{References}

1. G.N.Fursey, V.M.Zhukov. Sov. Phys., JTP, 1974, 44, 1280.

2. I.Yu.Bartashuis, I.I.Pranevichuis, G.N.Fursey. Sov. Phys., JTP, 1972, $41,9,1943$.

3. G.N.Fursey, V.M.Zhukov. Sov. Phys., JTP, 1976, 46, 2.

4. M.S.Aksenov et al. Radiotec. and Electron. Sov. Phys., 1978, 12,2600.

5. V.S.Voronin, A.N.Lebeder. Sov. Phys., JTP, $1973,43,12,2591$.

6. A.V.Agafonov, V.S.Voronin et a.. JTP, 1974, 44, 9, 1909.

7. V.S.Voronin et al. Plasma Phys., $1978,4,3,604$.

8. I.S.Bogdankevich, A.A.Ruchadze. Uspehi Phys. Nauk, 1971, 103, 609. 